\title{
Harmonisasi Peraturan Perundang-Undangan terhadap Bentuk Perjanjian Melalui Telemarketing
}

\author{
Andika Prawira Buana' ${ }^{1}$, Tri Abriana Ma'ruf ${ }^{2}$, Aan Aswari ${ }^{3 *}$ \\ 1,2,3 Ilmu Hukum, Universitas Muslim Indonesia \\ Email Correspondensi: aanaswari@umi.ac.id
}

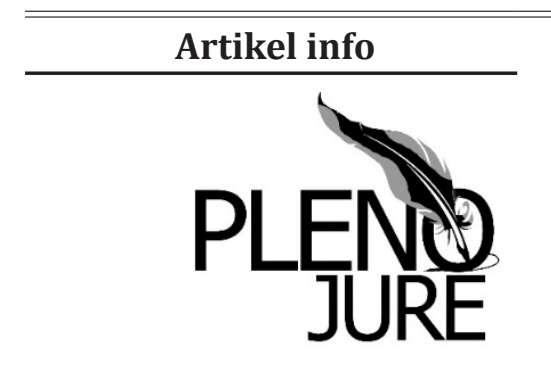

Jurnal Ilmu Hukum
LL-DIKTI Wilayah IX
Sulawesi

$\begin{array}{lr} & \text { Artikel history: } \\ \text { Received : } & \text { 11 Juni, 2019 } \\ \text { Revised : } & 16 \text { Juni, } 2019 \\ \text { Accepted : } & 15 \text { Agustus, } 2019\end{array}$

Keywords:

Harmonisasi;

Perjanjian;

Telemarketing.
Abstrak Perkembangan teknologi menimbulkan praktekpraktek perjanjian yang dalam implementasinya tidak lagi menjadi suatu hambatan demi terwujudnya kepastian hukum. Bentuk perjanjian melalui telemarketing adalah salah satu dari dampak perkembangan teknologi saat ini. Penelitian ini mencoba menganalisis legalitas pengaturan bentuk perjanjian telemarketing dalam peraturan perundang-undangan yang berlaku. Penelitian ini menggunakan jenis penelitian normatifyaitu menganalisis aturan perundang-undangan yang berkaitan dengan penelitian ini. Hasil penelitian ini menjawab praktek perjanjian telemarketing secara legalitasnya dalam beberapa ketentuan aturan perundang-undangan tidak lah menyalahi ketentuan, akan tetapi, dalam prakteknya perjanjian bentuk ini tidak dibenarkan karena terkait dengan sulitnya pembuktian, serta adanya ancaman pidana bagi pihak pelaku usaha yang menggunakan nomor seluler nasabah tanpa izin dari nasabah (konsumen).

Abstract. Technology development raises agreement practices that in its implementation are no longer an obstacle for the realization of legal certainty. This form of agreement through telemarketing is one of the effects of current technological developments. This study tries to analyze the legality of the arrangement of the form of telemarketing agreements in the applicable laws and regulations. This study uses a type of normative research that is analyzing statutory rules relating to this research. The results of this study answer the practice of the legality of the telemarketing agreement in a number of provisions of statutory regulations that don't violate the provisions, however, in practice this form of agreement is not justified because it is related to the difficulty of proof, and the criminal threat for business people who use the customer's cellular number without permission from customers (consumers).

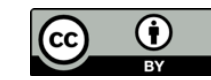

artikel dengan akses terbuka dibawah lisensi CC BY -4.0 


\section{PENDAHULUAN}

Perkembangan teknologi informasi yang kita kenal di era modern serta perkembangan bentuk-bentuk perjanjian melalui teknologi informasi dalam praktek perjanjian tentu menjadi harapan besar bagi masyarakat dapat memberikan manfaat guna terpenuhinya kebutuhan dan memberi kepastian hukum bagi para pihak. ${ }^{1}$ Praktek-praktek perjanjian sekarang ini tidak lagi mengharuskan para pihak untuk saling tatap muka untuk melakukan suatu pengikatan perjanjian. Praktek telemarketing misalnya, adalah sebuah bentuk perjanjian yang dilakukan oleh suatu perusahaan untuk menarik nasabah dengan modal yang sangat minim karena dilakukan hanya melalui via telepon. Pada prakteknya, telemarketing ini dilakukan oleh seorang telemarketer yang menghubungi nasabah dengan maksud dan tujuan untuk menawarkan produk barang atau jasa kepada nasabah. Praktek tersebut pada dasarnya adalah untuk memberikan kemudahan bagi nasabah dalam mengakses informasi dan mendapat produk baru dari perusahaan, akan tetapi praktek ini juga dapat menjadi boomerang bagi nasabah yang tidak teliti dan tidak paham mengenai praktek tersebut karena hanya membutuhkan kata 'iya' oleh nasabah dan rekaman percakapan antara nasabah dam telemarketer sebagai dasar kesepakatan untuk membuat pengikatan perjanjian. Berdasarkan wawancara awal yang dilakukan oleh penulis terhadap salah satu nasabah yang mengatakan bahwa, telemarketer dalam memberikan informasi terkait produk barang dan jasa yang ditawarkan tidak begitu jelas karena menggunakan bahasa yang sulit dipahami dan berbicara terlalu cepat. Nasabah juga mengatakan bahwa telemarketer di setiap akhir kalimat yang diucapkan selalu menambahkan kata 'iya' yang menurutnya secara tidak langsung memberikan sugesti kepada calon nasabah untuk juga mengatakan kata 'iya' yang menjadi dasar hukum kesepakatan bagi pihak telemarketer untuk membuat pengikatan perjanjian. Hal tersebut tentu bertentangan dengan Pasal 4 huruf c, Undang-Undang Nomor 8 Tahun 1999 tentang Perlindungan Konsumen yang menyatakan bahwa salah satu hak konsumen ialah "hak atas informasi yang benar, jelas dan jujur mengenai kondisi dan jaminan barang dan/atau jasa".

Tentu hal tersebut dapat menimbulkan masalah, sebab nasabah menganggap bahwa telemarketer melakukan sebuah penipuan karena tidak memberikan informasi yang jelas. Salah satu contoh permasalahan yang terjadi di dalam praktek pelaksanaan telemarketing adalah perkara yang diputus dalam putusan Nomor 85 K/Pdt.Sus-BPSK/2015, yakni seorang nasabah bernama Anggun Bestarivo Ernesia melawan PT. AXA Mandiri Financial Services. Dalam putusan tersebut nasabah merasa dirugikan oleh pihak asuransi karena dalam meminta persetujuan hanya melalui telemarketing untuk menyetujui melakukan pendebitan ulang dari rekening nasabah untuk memulihkan kembali polis asuransi yang telah mati dan

${ }^{1}$ Aswari, Aan, Buana, Andika Prawira, \& Rezah, Farah Syah. (2018). Harmonisasi Hukum Hak untuk Dilupakan bagi Koran Digital terhadap Calon Mahasiswa di Makassar. Kanun: Jurnal Ilmu Hukum, Universitas Syiah Kuala, 20(1), hlm. 43.

${ }^{2}$ Pasal 4 huruf c, Undang-Undang Nomor 8 Tahun 1999 tentang Perlindungan Konsumen. 
putus kontrak. $^{3}$

Artikel ini mengatakan, secara teori praktek perjanjian telemarketing belum sesuai dengan ketentuan aturan Perundang-undangan yang berlaku karena masih ada beberapa aturan yang bertentangan dengan bentuk perjanjian tersebut. Akan tetapi dalam prakteknya perjanjian telemarketing tersebut masih dipraktekkan hingga sekarang dan sudah menjadi hal biasa yang sebenarnya menjadi ancaman bagi masyarakat. Berdasarkan hal tersebut, artikel ini mengambil sebuah rumusan masalah yang menjadi fokus penelitian adalah, Bagaimanakah bentuk pengaturan perjanjian melalui telemarketing berdasarkan peraturan perundang-undangan yang berlaku?

\section{METODE}

Metode penelitian ini menggunakan jenis penelitian hukum normatif, yang mengkaji aturan perundang-undangan yang berkaitan dengan penelitian ini. Penelitian hukum normatif berfokus pada inventarisasi hukum positif yang berlaku, asas-asas dan doktrin hukum yang dikonsepkan sebagai norma yang berlaku dalam masyarakat dan menjadi acuan perilaku setiap orang.

\section{HASIL DAN PEMBAHASAN}

\section{A. Bentuk Pengaturan Perjanjian Melalui Telemarketing berdasarkan Peraturan Perundang-undangan}

\section{Kitab Undang-undang Hukum Perdata}

Perjanjian merupakan suatu perbuatan antara seorang pihak atau lebih yang melahirkan suatu perikatan untuk melaksanakan sesuatu yang telah disepakati. Berdasarkan Pasal 1313 KUHPerdata, persetujuan/perjanjian adalah suatu perbuatan di mana satu orang atau lebih mengikatkan diri terhadap satu orang lain atau lebih. Berdasarkan Pasal 1338 KUHPerdata, semua persetujuan/ perjanjian yang dibuat secara sah sesuai dengan Undang-undang berlaku sebagai Undang-undang bagi mereka yang membuatnya. ${ }^{4}$ Pasal tersebut mendeskripsikan bahwa semua perjanjian yang dibuat secara sah, mengikat bagi mereka yang telah sepakat untuk mengikatkan dirinya pada sebuah perjanjian. Akan tetapi, perlu juga dipahami bahwa setiap perjanjian memiliki syarat sah, berdasarkan ketentuan Pasal 1320 KUHPerdata, yakni kesepakatan para pihak, kecakapan para pihak, adanya objek perjanjian, dan suatu sebab yang halal menurut hukum positif. Syarat sah tersebut menjadi filter/batasan bagi setiap orang ataupun para pihak untuk melalukan perjanjian, agar perjanjian yang dibuat tetap berada

${ }^{3}$ Pratama, Adyan Agit, \& Turisno, Suradi Bambang Eko. (2017). Perlindungan Hukum Bagi Konsumen terhadap Perjanjian Perpanjangan Asuransi Melalui Telemarketing. Diponegoro Law Journal, Universitas Diponegoro, 6(1), hlm. 3.

${ }^{4}$ Pasal 1338, Kitab Undang-Undang Hukum Perdata 
pada aturan hukum yang baik dan benar. $^{5}$

Praktek telemarketing dalam sistemnya, sering membuat perjanjian secara lisan sebagai bukti bahwa telah terjadi perikatan antara pihak telemarketer dengan pihak konsumen. Perjanjian yang dibuat secara lisan tersebut, sebenarnya tidak mengurangi keabsahan perjanjian, sebab perjanjian yang dibuat itu tetap memenuhi ketentuan Pasal 1320 KUHPerdata yang mengatur tentang syarat sahnya perjanjian. Secara teoritik (law in books) yang merujuk pada Kitab undang-undang Hukum Perdata, sistem praktek perjanjian telemarketing tidak lah melanggar ketentuan perjanjian dan secara hakikat baik perjanjian itu dibuat secara lisan atau tertulis selama ada kesepakatan, kecakapan, objek, sebab yang halal serta itikad baik dari para pihak, perjanjian tersebut sah dan menjadi undang-undang bagi para pihak yang membuat, sebab KUHPerdata tidak mengatur ketentuan bahwa setiap perjanjian yang dibuat harus tertulis, ataupun tidak tertulis (lisan).

Menurut artikel ini, Pasal-Pasal yang memuat aturan perjanjian dalam KUHPerdata yang telah disebutkan diatas, pada hakikatnya tidak mengatur persoalan mengenai apakah perjanjian yang dibuat harus tertulis atau tidak tertulis (lisan). Akan tetapi dalam prakteknya di Indonesia perjanjian yang dibuat secara tidak tertulis atau lisan tidak dianjurkan, dengan pertimbangan bahwa ketika terjadi wanprestasi dalam pelaksanaan perjanjian itu, dalam kepentingan sebagai pembuktian di pengadilan untuk hal ganti rugi atau Perbuatan Melawan Hukum (onrechtmatige daad), setiap perjanjian yang dibuat wajib tertulis dan disertai materai sebagai pelunasan Bea Materai terhadap pajak dokumen.

Hal tersebutlah yang menjadi analisis bahwa, perjanjian melalui sistem telemarketing secara teori (ketentuan KUHPerdata) tidaklah menyalahi ketentuan dan tetap memiliki kekuatan hukum mengikat bagi para pihak (pacta sun servanda), akan tetapi secara praktek sistem perjanjian melalui telemarketing tidak lah tepat karena sifatnya yang tidak tertulis sehingga untuk kepentingan pembuktian di pengadilan sulit untuk diterima. Dan juga, perjanjian melalui telemarketing hanya berpihak pada debitur, karena sistem tersebut dalam bentuk rekaman suara dan hanya dimiliki oleh pihak debitur. Praktek telemarketing tersebut juga perlu dikaji berdasarkan ketentuan Perundang-undangan yang lain, agar tidak terjadi benturan norma, dan untuk mengetahui ketentuan hukum khusus mana, yang mengatur terkait sistem perjanjian secara telemarketing. 


\section{Undang-undang Nomor 8 Tahun 1999 tentang Perlindungan Konsumen}

Pasal 4 huruf c Undang-Undang Nomor 8 Tahun 1999 tentang Perlindungan Konsumen pada, menyatakan bahwa salah satu hak konsumen ialah "hak atas informasi yang benar, jelas dan jujur mengenai kondisi dan jaminan barang dan/atau jasa. ${ }^{6}$ Pasal tersebut menjelaskan bahwa, konsumen wajib memperoleh informasi apapun terkait barang/jasa yang diperdagangkan secara benar dan jelas dan juga pelaku usaha wajib menginformasikannya secara jelas dan jujur.

Praktek telemarketing dalam menjalankan sistemnya hanya menekankan pada aspek kepentingan perusahaan untuk mendapat keuntungan sebesar-besarnya dan mengabaikan hak-hak konsumen yang tertuang dalam Undang-undang Nomor 8 Tahun 1999 tentang Perlindungan Konsumen. Berdasarkan tugas dan fungsi telemarketer pada hakikatnya memiliki tujuan yang baik yaitu menyajikan dan mengenalkan brand, produk, maupun jasa pada potential prospek konsumen atau para buyer dengan jelas dan jujur. ${ }^{7}$ Akan tetapi, beban target tinggi yang diberikan perusahaan kepada telemarketer menjadi penyebab pihak telemarketer tidak dengan jelas dan jujur dalam menyajikan dan mengenalkan brand, produk kepada konsumen, sehingga mengabaikan hak-hak konsumen. Hal tersebut tentu bertentangan dengan Pasal 4 huruf c Undang-undang Nomor 8 Tahun 1999 tentang Perlindungan Konsumen.

Pasal 7 huruf b Undang-undang Nomor 8 Tahun 1999 tentang Perlindungan Konsumen, menyatakan pelaku usaha berkewajiban "memberikan informasi yang benar, jelas dan jujur mengenai kondisi dan jaminan barang dan/atau jasa serta memberi penjelasan penggunaan, perbaikan dan pemeliharaan". Pasal tersebut juga menjelaskan bahwa setiap pelaku usaha mempunyai kewajiban yang sebagaimana tertuang dalam Pasal 7 huruf b, oleh karenanya menurut penulis, Undang-undang Nomor 8 Tahun 1999 tentang Perlindungan Konsumen juga secara tegas melarang bentuk perjanjian telemarketing yang berdasarkan UUPK menyampingkan hak-hak konsumen untuk mendapatkan informasi yang jelas dan dalam prakteknya demi mendapatkan keuntungan yang sebesarbesarnya pihak telemarketer tetap menyampingkan hak-hak konsumen, yang berimplikasi terjadi perbuatan melawan hukum (PMH).

${ }^{6}$ Pasal 4 huruf c, Undang-Undang Nomor 8 Tahun 1999 tentang Perlindungan Konsumen

${ }^{7}$ Groedu Academy E-Learning, (2018). Ketahui Perbedaan dan Tugas-Tugas Antara Telemarketing dan Telesales. Dari laman http://groeduacademy.com/?tag=tugas-tugas-yangmembedakan-telemarketing-dan-telesales, (diakses, 20 Maret 2019)

${ }^{8}$ Pasal 7 huruf b, Undang-Undang Nomor 8 Tahun 1999 tentang Perlindungan Konsumen. 


\section{Undang-undang Nomor 19 Tahun 2016 tentang Perubahan Atas Undang-undang Nomor 11 Tahun 2008 tentang Informasi dan Transaksi Elektronik}

Informasi elektronik adalah satu atau sekumpulan data elektronik, termasuk tetapi tidak terbatas pada tulisan, suara, gambar, peta, rancangan, foto, electronic data interchange (EDI), surat elektronik (electronic mail), telegram, teleks, telecopy, atau sejenisnya, huruf, tanda, angka, kode akses, simbol, atau perforasi yang telah diolah yang memiliki arti atau dapat dipahami oleh orang yang mampu memahaminya. ${ }^{9}$ Selanjutnya, Transaksi Elektronik adalah perbuatan hukum yang dilakukan dengan menggunakan computer, jaringan computer, dan/atau media elektronik lainnya. ${ }^{10}$

Bentuk perjanjian melalui telemarketing berdasarkan ketentuan UU ITE, termasuk pada kategori informasi elektronik sesuai ketentuan Pasal 1 angka 1 Undang-undang Nomor 19 Tahun 2016 tentang Perubahan Atas Undang-undang Nomor 11 Tahun 2008 tentang Informasi dan Transaksi Elektronik karena termasuk data elektronik melalui suara. Praktek telemarketing ini pada dasarnya diakui keberadaannya, sebab mengacu pada Asas Kebebasan Berkontrak yang orientasinya pada kepentingan individu masingmasing yang memiliki kebebasan untuk membuat perjanjian yang menimbulkan perikatan. ${ }^{11}$ Asas ini memiliki korelasi positif dengan akibat dari perjanjian, asas ini terdapat dalam Pasal 1338 ayat (1) Kitab Undang-undang Hukum Perdata (BW), bahwa segala perjanjian yang telah dibuat secara sah oleh para pihak akan berlaku sebagai undang-undang bagi yang membuatnya. Perjanjian ini tidak dapat diubah kembali selain dengan kesepakatan masing-masing pihak atau karena alasan-alasan yang ditentukan oleh Undang-undang. ${ }^{12}$

Akan tetapi, yang menjadi perhatian kemudian adalah pembuktian, sesuai pada pembahasan dalam KUHPerdata terkait pembuktian. Undang-undang Nomor 19 Tahun 2016 tentang Perubahan Atas Undang-undang Nomor 11 Tahun 2008 tentang Informasi dan Transaksi Elektronik juga mengatur tentang pembuktian dalam sengketa memalui sistem elektronik, dalam UU ITE prinsip pembuktian terkait dengan hal-hal yang harus dibuktikan dalam peristiwa atau hak yang mengandung sengketa atau perselisihan yang diajukan oleh salah satu pihak dan disangkal oleh pihak lain seperti dalam Pasal 1865 KUHPerdata ini juga ada dalam Pasal 7 Undang-undang Nomor 11 Tahun 2008 tentang

${ }^{9}$ Pasal 1 angka 1, Undang-Undang Nomor 19 Tahun 2016 tentang Perubahan Atas Undangundang Nomor 11 Tahun 2008 tentang Informasi dan Transaksi Elektronik.

${ }^{10}$ Pasal 1 angka 2, Undang-Undang Nomor 19 Tahun 2016 tentang Perubahan Atas Undangundang Nomor 11 Tahun 2008 tentang Informasi dan Transaksi Elektronik.

${ }^{11}$ Sugiyanto, Didik Wahyu. (2017). Perjanjian Asuransi Melalui Telemarketing Ditinjau dari Undang-Undang Nomor 11 Tahun 2008. Mimbar Yustitia, Universitas Islam Darul Ulum, 1(1), hlm. 37.

${ }^{12}$ Ibid. 
Informasi dan Transaksi Elektronik, yang menyatakan bahwa:

"Setiap orang yang menyatakan hak, memperkuat hak yang telah ada, atau menolak hak orang lain berdasarkan adanya informasi elektronik dan/atau dokumen elektronik harus memastikan bahwa informasi elektronik dan/atau dokumen elektronik yang ada berasal dari sistem elektronik yang memenuhi syarat berdasarkan peraturan perundang-undangan". ${ }^{13}$

Keabsahan dan kekuatan pembuktian alat bukti elektronik berdasarkan UU ITE, diatur dalam Pasal 5 ayat (1) Undang-undang Nomor 11 Tahun 2008 tentang Informasi dan Transaksi Elektronik, bahwa "informasi elektronik dan/atau dokumen elektronik dan/atau hasil cetaknya merupakan alat bukti hukum yang sah". Kemudian pada ayat (2) menyatakan bahwa, "Informasi Elektronik dan/atau Dokumen Elektronik dan/atau hasil cetaknya sebagaimana dimaksud pada ayat (1) merupakan perluasan dari alat bukti yang sah sesuai dengan Hukum Acara yang berlaku di Indonesia". Pasal tersebut secara tegas, menjelaskan bahwa dokumen elektronik, baik itu hasil cetak ataupun rekaman suara merupakan alat bukti yang sah dan sesuai dengan ketentuan aturan perundang-undangan. ${ }^{14}$

Putusan Hakim No.769K/Pdt.Sus/2011 tentang perdata khusus sengketa konsumen dalam tingkat kasasi yang dalam pertimbangan hukum hakim memandang alat bukti berupa rekaman percakapan ini sah sebagai alat bukti sah namun selain alat bukti rekaman percakapan pihak pemohon juga mengajukan alat bukti lain yaitu alat bukti tertulis mengenai akta pembukaan rekening tabungan nasabah. Dalam putusan perkara perdata ini hakim mengabulkan permohonan kasasi pihak pemohon. Selain itu dalam kasus yang berbeda dalam Putusan Mahkamah Agung No.46/Pdt.G/2013/PN.KPG tentang perkara perdata. Hakim dalam perkara ini juga dalam perkara ini penggugat mengajukan rekaman pembicaraan sebagai alat bukti. Dalam pertimbangan hukum oleh hakim dalam putusan perkara perdata ini rekaman pembicaraan telepon yang diajukan oleh penggugat dianggap sebagai alat bukti "persangkaan" sehingga perlu adanya alat bukti tambahan untuk meyakinkan hakim dalam memutus perkara seperti dalam kasus ini yaitu berupa surat perjanjian yang dianggap oleh para hakim dapat meyakinkan hakim dalam memutus perkara ini. Selain bukti yang diajukan penggugat berupa rekaman pembicaraan telepon tersebut. ${ }^{15}$

${ }^{13}$ Ibid.

${ }^{14}$ Pasal 5 ayat (1) dan (2), Undang-Undang Nomor 19 Tahun 2016 tentang Perubahan Atas Undang-undang Nomor 11 Tahun 2008 tentang Informasi dan Transaksi Elektronik.

${ }^{15}$ Sugiyanto, Didik Wahyu. (2017). Loc. Cit. 
Oleh sebab itu menurut artikel ini, secara hakikat perjanjian melalui telemarketing tidaklah menyalahi ketentuan UU ITE, karena tetap berada pada syarat-syarat dan asas-asas perjanjian yang benar, akan tetapi sama hal nya berdasarkan analisis menurut KUHPerdata, yang menempatkan pembuktian terhadap sengketa perdata atas perjanjian telemarketing masih membutuhkan alat bukti yang lainnya, dalam hal ini, konsumen (nasabah) akan menjadi kesulitan untuk membuktikan sengketa perdata tersebut sebab keutuhan dan bentuk pertanggungjawaban rekaman suara sulit diakses dan ditampilkan oleh konsumen karena rekaman hanya dimiliki pihak telemarketer (pelaku usaha).

\section{Undang-undang Nomor 14 Tahun 2008 tentang Keterbukaan Informasi Publik}

Praktek perjanjian telemarketing yang dalam sistemnya hanya menghubungi nasabah (konsumen) melalui telepon seluler yang terkadang menimbulkan pertanyaan oleh konsumen, jikalau nomor telepon seluler konsumen diperoleh dari mana?. Persoalan kemudian adalah nomor telepon seluler tersebut berpindah tangan dari telemarketing yang satu kepada telemarketing yang lainnya. Hal tersebut tentu menimbulkan gangguan kepada konsumen yang secara bergantian mendapatkan telepon dari pihak telemarketer. Atas persoalan tersebut bagaimana kah perlindungan data pribadi konsumen dalam hal ini nomor telepon seluler yang diperoleh oleh orang lain.

Perlindungan kerahasiaan nomor seluler tersebut termuat dalam Pasal 17 hurufh Undang-undang Nomor 14 Tahun 2008 tentang Keterbukaan Informasi Publik bahwa "informasi pribadi, termasuk aset dan nomor telepon pribadi seseorang merupakan informasi yang dikecualikan, atau rahasia, "Bahkan, ada ancaman pidana hingga 2 (dua) tahun penjara bagi pihak-pihak yang membocorkan informasi pribadi" ${ }^{16}$ Ketentuan peraturan perundang-undangan tersebut tentu memberikan gambaran yang jelas bahwasanya nomor seluler tidak boleh diberikan kepada siapapun tanpa izin dari pemilik nomor telepon seluler. Bentuk perjanjian telemarketing dalam hal nomor telepon seluler nasabah yang diperoleh tanpa seizin dari nasabah, tentu menimbulkan ancaman pidana. Akan tetapi, praktek tersebut hingga kini masih berlangsung dan belum adanya "law enforcement" atas bentuk perjanjian tersebut.

Selain itu, OJK juga meminta industri perbankan dan jasa keuangan untuk menghentikan penawaran melalui pesan pendek ataupun panggilan telepon. Larangan yang tertuang dalam Peraturan OJK Nomor 1/POJK.7/2013 yang terbit mulai berlaku efektif 6 Agustus 2014 yang lalu. Menurut Peraturan OJK, penawaran harus

${ }^{16}$ Pasal 17 huruf h, Undang-Undang Nomor 14 Tahun 2008 tentang Keterbukaan Informasi Publik. 
dilakukan atas persetujuan konsumen atau calon konsumen terlebih dahulu. Untuk itu, OJK telah berkoordinasi dengan Kementerian Komunikasi dan Informatika serta Badan Regulator Telekomunikasi Indonesia (BRTI) untuk menangani operator yang kerap mengirim SMS atau spam promosi bank. Tentu saja OJK akan mencarikan payung hukum yang pas dan pihaknya sedang berusaha berbicara dengan Menkominfo, terkait bagaimana (aturan) yang efektif. ${ }^{17}$ OJK akan terlebih dulu melakukan pendekatan persuasif kepada pelaku jasa keuangan karena hal tersebut di dalamnya terdapat isu perlindungan konsumen. OJK akan melakukan pembinaan kepada pelaku jasa keuangan dan juga pihak ketiga selaku operator yang bekerja untuk lembaga keuangan tersebut. Penawaran produk melalui SMS dan telepon memang sudah cukup banyak yang mengkhawatirkan. Kebanyakan laporan pengaduan yang diterima oleh OJK yakni terkait penawaran kredit Tanpa Agunan (KTA) atau kartu kredit.

\section{B. Analisis Peraturan Perundang-undangan Terkait}

Berdasarkan beberapa aturan Perundang-undangan yang telah dijelaskan sebelumnya menurut artikel ini bahwa, praktek perjanjian telemarketing berdasarkan ketentuan Kitab Undang-undang Hukum Perdata, Undang-undang Nomor 8 Tahun 1999 tentang Perlindungan Konsumen dan Undang-undang Nomor 19 Tahun 2016 tentang Atas Perubahan Undang-undang Nomor 11 Tahun 2008 tentang Informasi dan Transaksi elektronik, secara teori hukum positif tidaklah menyalahi ketentuan peraturan perundang-undangan. Akan tetapi, bentuk pertanggung jawaban dan bentuk pembuktian ketika terjadi sengketa perdata serta penyampingan hak-hak konsumen yang menyebabkan bentuk perjanjian melalui telemarketing ini pada prakteknya tidak dibenarkan. Perjanjian pada hakikatnya menggunakan metode analogi terhadap hubungan hukum antara subjek hukum yang satu dengan subjek hukum yang lain dengan sepakat untuk mengingatkan diri dalam bentuk perikatan dan merujuk berdasarkan ketentuan yang diatur pada Peraturan Perundang-undangan. ${ }^{18}$

Berdasarkan hakikat dari perjanjian yang dilakukan antara subjek hukum sejatinya memiliki kedudukan yang sama dan mendapat perlindungan hukum terhadap masing-masing pihak serta tidak merugikan salah satu pihak yang disebabkan karena kurangnya informasi terhadap objek yang diperjanjikan. Hal ini tidak hanya berlaku

${ }^{17}$ hukumonline.com. (2014). Langkah OJK Larang Telemarketing Dinilai Tepat: OJK Akan Melakukan Pembinaan Kepada Pelaku Jasa Keuangan dan Pihak Ketiga Selaku Operator yang Bekerja untuk Lembaga Keuangan Tersebut. Dari laman https://www.hukumonline.com/berita/ baca/lt5391b5609b7fc/langkah-ojk-larang-telemarketing-dinilai-tepat (diakses pada tanggal 21 Maret 2019).

${ }^{18}$ Aswari, Aan, Pasamai, Syamsuddin, Qamar, Nurul, \& Abbas, Ilham. (2017). Legal Security on Cellphone Trading Through Electronic Media in Indonesia. Jurnal Dinamika Hukum, Universitas Jenderal Soedirman, 17(2), hlm. 184. 
pada bentuk perjanjian konvensional, akan tetapi juga berlaku pada bentuk perjanjian elektronik. Transaksi elektronik merupakan bagian dari pada hukum perikatan yang mengikat para pihak dan sesuai dengan ketentuan Pasal 1233 KUHPerdata yang menyatakan bahwa perikatan lahir karena persetujuan (perjanjian) atau karena Undang-undang. Transaksi elektronik tersebut tentunya akan merujuk pada semua mekanisme dalam melakukan hubungan hukum walaupun bentuk untuk melakukan perikatan itu mengalami perubahan di masyarakat, seperti halnya perjanjian melalui telemarketing. ${ }^{19}$

Perjanjian melalui telemarketing merupakan bentuk perjanjian yang berkembang di dalam masyarakat dan dalam prakteknya secara umum, perjanjian ini banyak digunakan oleh Lembaga perbankan untuk memberikan penawaran terhadap konsumen berupa produkproduk perbankan (pinjaman, asuransi, tabungan). Menurut artikel ini, produk perbankan tersebut dalam proses memahami isi perjanjiannya memerlukan mekanisme tatap muka secara langsung agar tidak terjadi miss communication yang dapat menimbulkan perbuatan melawan hukum di kemudian hari yang disebabkan kurangnya informasi. PMH yang terjadi dari perjanjian melalui telemarketing selalu menempatkan konsumen dalam posisi pihak yang melakukan wanprestasi. Namun informasi yang diperoleh dari beberapa konsumen, pada aspek lainnya konsumen juga sering berdalih bahwa pihaknya lah yang merasa dirugikan karena merasa bahwa kurangnya informasi yang diperoleh dari perjanjian tersebut. Konsumen juga mengatakan bahwa perjanjian itu hanyalah sepihak, karena dalam mekanisme penawarannya konsumen terkadang tidak dalam kondisi yang siap menerima informasi karena sedang melakukan aktifitas lain dan mendapat telepon/penawaran dari pihak telemarketing.

Konsensus yang menjelaskan untuk menyesuaikan kehendak yang merupakan ketentuan wajib dalam setiap perikatan dan termuat dalam Pasal 1320 KUHPerdata dalam bentuk syarat pertama dalam perjanjian yaitu kesepakatan. ${ }^{20}$ Konsensus yang memiliki arti perjanjian itu terjadi ketika kata sepakat antara para pihak, sehingga dapat dikatakan bahwa perjanjian tersebut sah dan mempunyai kekuatan hukum yang mengikat sejak terjadinya kesepakatan antara para pihak mengenai isi perjanjian yang dimaksudkan. Perjanjian melalui telemarketing yang memberikan informasi yang tidak jelas dan menggunakan bahasa yang sulit dipahami, dapat diartikan konsensus untuk mencapai kesepakatan tidak dapat terwujud dengan kata lain perjanjian tersebut dapat dikatakan batal

${ }^{19}$ Ilyas. (2012). Keabsahan Perjanjian Asuransi Melalui Telemarketing Ditinjau dari UndangUndang Nomor 11 Tahun 2008. Kanun: Jurnal Ilmu Hukum, Universitas Syiah Kuala, 14(2), hlm. 202.

${ }^{20}$ Paramarta, Nabhila Palupi, Sulistyorini, Rachmi, \& Alam, M. Zairul. (2014). Analisis Yuridis Mengenai Rekaman Pembicaraan Telepon sebagai Alat Bukti dalam Perjanjian Asuransi melalui Telemarketing (Ditinjau dari Undang-Undang No. 11 Tahun 2008 Tentang Informasi dan Transaksi Elektronik). Kumpulan Jurnal Mahasiswa Fakultas Hukum, Hukum Universitas Brawijaya, 1(1), hlm. 10 . 
demi hukum.

Perjanjian melalui telemarketing juga memungkinkan tidak terpenuhi nya asas itikad baik yang disebabkan pihak telemarketing dalam melaksanakan perjanjian cenderung menyampingkan hakhak konsumen dengan memberikan informasi yang tidak jelas demi tercapainya target yang diberikan oleh perusahaan. Itikad baik itu juga tidak terpenuhi dikarenakan sulitnya konsumen mengajukan komplain terhadap perjanjian yang disepakati, sehingga dalam pelaksanaannya sering menimbulkan permasalahan. Hal ini tentu yang mendasari bahwa perjanjian melalui telemarketing dapat pula dikatakan batal demi hukum karena menyampingkan ketentuan Pasal 1338 ayat (1) KUHPerdata bahwa persetujuan-persetujuan harus dilakukan dengan itikad baik. ${ }^{21}$

Atas pandangan tersebutlah sehingga menurut artikel ini dalam praktek perjanjian melalui telemarketing tidak dibenarkan karena tidak semua konsumen memiliki pemahaman dan kesadaran hukum terhadap bentuk perjanjian ini. Perjanjian melalui telemarketing juga tidak dilakukan berdasarkan prinsip-prinsip hukum perjanjian, sehingga dalam pelaksanaannya sering menimbulkan permasalahan bahkan menjadikan nasabah (konsumen) sebagai pihak yang melakukan wanprestasi karena tidak melakukan hal yang harus dilakukan. ${ }^{22}$ Ketentuan Perundang-undangan lain juga menekankan larangan bentuk perjanjian telemarketing ini adalah Undang-undang Nomor 14 Tahun 2008 tentang Keterbukaan Informasi Publik. Larangan tersebut menekankan pada tidak bolehnya nomor telepon seluler nasabah diberikan kepada pihak lain tanpa seizin dari pemilik nomor telepon dan memberikan ancaman pidana bagi siapa saja yang melanggar. Hal ini tentu bertentangan dengan perjanjian melalui telemarketing yang dalam menjalankan prakteknya secara langsung menghubungi nasabah melalui telepon selular, padahal nasabah tidak pernah mengetahui dari mana nomor telepon selular miliknya didapatkan.

\section{SIMPULAN DAN SARAN}

Bentuk pengaturan praktek perjanjian telemarketing dalam Peraturan Perundang-undangan tidaklah menyalahi ketentuan secara materi hukum positif, terkhusus yang termuat pada Kitab Undang-undang Hukum Perdata, Undang-undang Nomor 8 Tahun 1999 tentang Perlindungan Konsumen dan Undang-undang Nomor 19 Tahun 2016 tentang Atas Perubahan Undangundang Nomor 11 Tahun 2008 tentang Informasi dan Transaksi elektronik. Akan tetapi pada prakteknya, bentuk perjanjian ini tidak dibenarkan sebab dalam hal terjadi sengketa karena bentuk perjanjian ini sulit untuk dibuktikan oleh karena keutuhan dan bentuk pertanggungjawaban rekaman suara susah diakses dan ditampilkan oleh konsumen karena rekaman hanya

\footnotetext{
${ }^{21}$ Ibid., hlm. 11.

${ }^{22}$ Perdana, Afrilian, Dahlan, \& Mahfud. (2014). Penyelesaian Wanprestasi dalam Perjanjian Jual Beli Melalui Media Elektronik. Jurnal Ilmu Hukum, Universitas Syiah Kuala, 2(1), hlm. 54.
} 
dimiliki pihak telemarketer. Bahkan dalam ketentuan Perundang undangundang yang lain mengatur sanksi pidana bagi pihak yang memberikan nomor telepon seluler tanpa izin yang berhak. Pemerintah dalam hal ini Lembaga Negara serta Kementerian terkait perlu menetapkan payung hukum untuk mengatur tentang larangan bentuk perjanjian telemarketing tersebut dan melakukan bentuk law enforcement. Masyarakat pun dituntut untuk meningkatkan kesadaran hukum agar mengetahui apa apa yang menjadi hak serta kewajiban konsumen berdasarkan Peraturan Perundangundangan.

\section{UNGKAPAN TERIMAKASIH}

Seluruh penulis mengucapkan banyak terima kasih yang sebesarbesarnya kepada Universitas Muslim Indonesia (UMI) terkhusus kepada Fakultas Hukum dan Lembaga Penelitian dan Pengembangan Sumberdaya (LP2S-UMI) sebagai pihak yang mendukung proses penyelesaian penulisan artikel ini.

\section{DAFTAR RUJUKAN}

Aswari, Aan, Buana, Andika Prawira, \& Rezah, Farah Syah. (2018). Harmonisasi Hukum Hak untuk Dilupakan bagi Koran Digital terhadap Calon Mahasiswa di Makassar. Kanun: Jurnal Ilmu Hukum, Universitas Syiah Kuala, 20(1), 39 - 62.

Aswari, Aan, Pasamai, Syamsuddin, Qamar, Nurul, \& Abbas, Ilham. (2017). Legal Security on Cellphone Trading Through Electronic Media in Indonesia. Jurnal Dinamika Hukum, Universitas Jenderal Soedirman, 17(2), $181-187$.

hukumonline.com. (2014). Langkah OJK Larang Telemarketing Dinilai Tepat: OJK Akan Melakukan Pembinaan Kepada Pelaku Jasa Keuangan dan Pihak Ketiga Selaku Operator yang Bekerja untuk Lembaga Keuangan Tersebut. Retrieved from https://www.hukumonline.com/berita/ baca/lt5391b5609b7fc/langkah-ojk-larang-telemarketing-dinilaitepat

Ilyas. (2012). Keabsahan Perjanjian Asuransi Melalui Telemarketing Ditinjau dari Undang-Undang Nomor 11 Tahun 2008. Kanun: Jurnal Ilmu Hukum, Universitas Syiah Kuala, 14(2), 201 - 215.

Ketahui Perbedaan dan Tugas-Tugas Antara Telemarketing dan Telesales. (2018). Retrieved from http://groeduacademy.com/?tag=tugastugas-yang-membedakan-telemarketing-dan-telesales

Paramarta, Nabhila Palupi, Sulistyorini, Rachmi, \& Alam, M. Zairul. (2014). Analisis Yuridis Mengenai Rekaman Pembicaraan Telepon sebagai Alat Bukti dalam Perjanjian Asuransi melalui Telemarketing (Ditinjau dari Undang-Undang No. 11 Tahun 2008 Tentang Informasi dan Transaksi Elektronik). Kumpulan Jurnal Mahasiswa Fakultas Hukum, Hukum Universitas Brawijaya, 1(1), 1 - 14. 
Pleno Jure, Vol. 9 (2), Andika Prawira Buana, Harmonisasi Peraturan ...

Perdana, Afrilian, Dahlan, \& Mahfud. (2014). Penyelesaian Wanprestasi dalam Perjanjian Jual Beli Melalui Media Elektronik. Jurnal Ilmu Hukum, Universitas Syiah Kuala, 2(1), 52 - 57.

Pratama, Adyan Agit, \& Turisno, Suradi Bambang Eko. (2017). Perlindungan Hukum Bagi Konsumen terhadap Perjanjian Perpanjangan Asuransi Melalui Telemarketing. Diponegoro Law Journal, Universitas Diponegoro, 6(1), 1 - 21.

Sugiyanto, Didik Wahyu. (2017). Perjanjian Asuransi Melalui Telemarketing Ditinjau dari Undang-Undang Nomor 11 Tahun 2008. Mimbar Yustitia, Universitas Islam Darul Ulum, 1(1), 36 - 45.

Kitab Undang-Undang Hukum Perdata.

Undang-Undang Republik Indonesia Nomor 8 Tahun 1999 tentang Perlindungan Konsumen.

Undang-Undang Republik Indonesia Nomor 14 Tahun 2008 tentang Keterbukaan Informasi Publik.

Undang-Undang Republik Indonesia Nomor 19 Tahun 2016, sebagaimana perubahan atas Undang-Undang Nomor 11 tahun 2009 tentang Informasi dan Transaksi Elektronik 